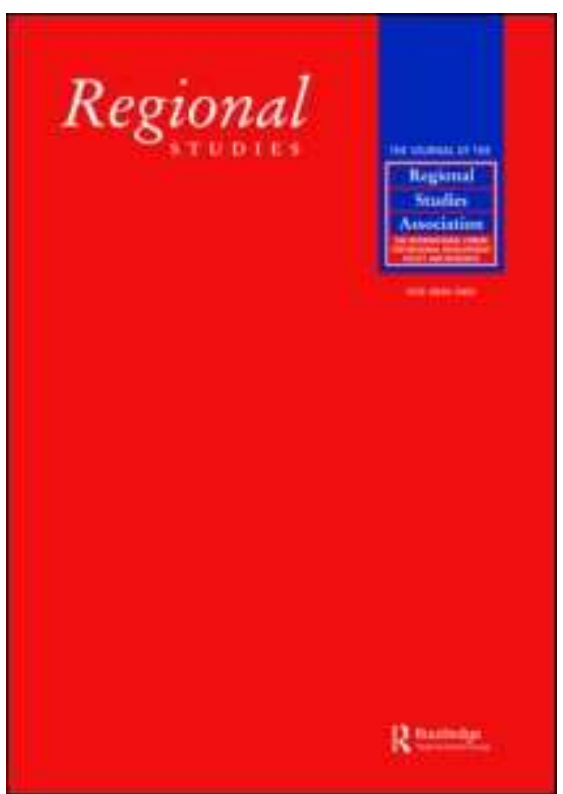

\title{
Group-Specific Effects of Interregional Mobility on Earnings - A Microdata Analysis for Germany
}

\begin{tabular}{|r|l|}
\hline Journal: & Regional Studies \\
\hline Manuscript ID: & CRES-2005-0036.R3 \\
\hline Manuscript Type: & Main Section \\
\hline JEL codes: & $\begin{array}{l}\text { J61 - Geographic Labor Mobility |Immigrant Workers < J6 - Mobility, } \\
\text { Enemployment, and Vacancies < J - Labor and Demographic } \\
\text { Markets|Population < R2 - Household Analysis < R - Urban, Rural, } \\
\text { and Regional Economics }\end{array}$ \\
\hline Keywords: & $\begin{array}{l}\text { propensity score matching, unobserved heterogeneity, Inter- } \\
\text { regional mobility, decomposition of wage differentials, mobility } \\
\text { wage differentials }\end{array}$ \\
\hline
\end{tabular}

\section{SCHOLARONE" Manuscripts}




\title{
Group-Specific Effects of Interregional Mobility on
} Earnings A Microdata Analysis for Germany

\author{
Florian LEHMER* \\ Joachim MÖLLER** \\ * Department of Economics, University of Regensburg \\ Universitätsstraße 31, D-93053 Regensburg, Germany, \\ ** Department of Economics, University of Regensburg \\ Universitätsstraße 31, D-93053 Regensburg, Germany \\ Emails: florian.lehmer@wiwi.uni-regensburg.de; joachim.moeller@wiwi.uni- \\ regensburg.de
}

\section{March 2007}

\section{Abstract}

The paper analyses the relationship between regional mobility and earnings for different groups of workers. Using a large panel microdata set we find negative earnings differentials of movers in the year before migration and strong evidence for significant wage gains through mobility. A decomposition of Blinder/ Oaxaca type reveals different group-specific rewards effects suggesting a positive postmobility wage differential of movers over the incumbent workforce for some groups irrespective of the region of destination. The existence of a general wage growth effect of mobility appears to be robust and cannot be explained by the time-invariant part of unobserved heterogeneity.

\section{Keywords:}

Inter-regional mobility, migration wage differentials, unobserved heterogeneity, propensity score matching.

JEL-classification: J61, R23 


\section{Introduction}

Given the importance of the economic policy debate on labour market flexibility and labour market reforms especially in continental Europe, there is a renewed interest in the various dimensions of labour mobility. Workers move within and between occupations, firms and industries. Some of these moves take place within the same region while others are connected with a change in the region where the workplace is located. The pioneering studies of MINCER and JOVANOVICH (1981) and BARTEL and BORJAS (1981) deal with the correlation of job mobility and wages. Aspects like geographical, industrial and occupational mobility are taken as components of overall job mobility and not treated separately. Both studies stress the consequences of labour turnover for the worker's experience rating: while young workers experience significant wage gains when changing the employer voluntarily, it cannot be predicted how differences in mobility during the first ten years of working life affect the workers' lifetime wage path.

Following these two seminal contributions to research in labour mobility, much effort has been devoted to assessing the relationship between early job mobility and wages also in the context of the theory of general and firm-specific human capital ${ }^{1}$ (e.g. BARTEL, 1980; MINCER, 1986; ANTEL, 1991; TOPEL and WARD, 1992) ${ }^{2}$. All these studies measure the immediate gains of movers typically as between-job wage growth. Mobility reflects the workers' search for better jobs. Even in the early literature this was associated with the realization of individual comparative advantages (JOHNSON, 1978), high-quality job matches (JOVANOVICH, 1979) or simply a move to better paid jobs (BURDETT, 1978).

The cited studies stress the positive effects of job mobility on wages. However, there may also be negative effects. Typically, workers (and firms) invest in firm-specific human capital and the individual wage increases with the stock of acquired skills that makes the worker more productive within the firm. By changing the employer the worker can no longer profit from his or her firm-specific skills. Some empirical evidence supports this view. LIGHT and MCGARRY (1998, p.276), for instance, find “... that workers who undergo persistent mobility have lower log-wage paths than less mobile workers". This result is corroborated by more recent studies like MUNASINGHE and SIGMAN (2004). 
Another strand of the literature explicitly deals with the determinants of job changes (FARBER, 1999) and the differences in occupational mobility patterns (HEITMUELLER, 2004).

The regional dimension of mobility has been stressed by a number of studies following the pioneer work of HARRIS and TODARO (1970). ANTOLIN and BOVER (1997) and PISSARIDES and WADSWORTH $(1989)^{3}$, among others, examine how unemployment affects the inter-regional migration of labour. The employment prospects of unemployed migrants are highlighted in PEKKALA and TERVO (2002), for instance. The effect of migration on post-move employment (e.g. TERVO, 2000) can also be considered within the context of family decisions (see, for instance, NIVALAINEN, 2005). In contrast to the vast literature on the economic consequences of immigration (e.g. BORJAS, 1994; HAISKEN-DENEW, 1996), less effort has been devoted to the wage effect of inter-regional mobility within a country. Exceptions are especially found for Scandinavian countries. NAKOSTEEN and WESTERLUND (2004) for Sweden and PEKKALA (2002) for Finland both observe significant income gains from migration. For Germany, Jennifer HUNT (2004) investigated migration streams using the German Socio Economic Panel (GSOEP). She stresses the importance of inter-state migration without changing the employer. According to her results, this group represents about one fifth of all migrants and is characterized by higher skills and has higher pre-move wages than the group of non-migrants.

The impact of migration on wages has been considered explicitly from a spatial job search perspective by DETANG-DÉSSENDRE, DRAPIER and JAYET (2004) using data for young Frenchmen. Taking the possibility of self-selection into account they find no selection effect for low-educated migrants and a positive one for highly-educated ones, especially for those who move to Ile-de-France.

The specific impact of rural-urban mobility on the level and growth rates of individual wages has been analyzed by GLAESER and MARE (2001) with U.S. data. They find that workers moving from rural to metropolitan areas experience significant wage gains immediately after migration, which supports the existence of an urban wage premium. However, although movers benefit from migration to metropolitan areas, they typically fall behind the incumbent urban workforce. This wage disadvantage is gradually reduced by a wage-growth effect induced by migration. GLAESER and MARÈ (2001) argue that these effects stem from faster accumulation of human capital in cities leading to a rise in the urban 
wage premium over time. Hence, wages are highest for individuals staying in these areas for a longer period.

The immediate wage gains after rural-urban migration corroborate the existence of a so-called wagelevel effect being associated with the migration of workers to cities. The wage level hypothesis can be justified by arguing that wages in cities are higher than in rural areas because of higher demand in cities and cheaper inputs due to the proximity of suppliers of intermediate goods, for example. ${ }^{4}$ The hypothesis would imply a marked decline in wages if workers left the metropolitan area. According to GLAESER and MARÈ (2001), however, this is not observed empirically. Workers typically face no wage losses if they move away from cities. This is in accordance with PERI (2001), who presents a theoretical model explaining why highly-educated young workers are attracted to big cities and why some of these workers move to less dense areas when old.

The aim of our paper is to investigate the relationship between inter-regional mobility and earnings from several perspectives. Controlling for their observed characteristics such as skills, experience and gender, we examine the wage differentials between mobile workers and their immobile counterparts. Like GLAESER and MARÈ (2001) we analyze the earnings of movers before and after migration in order to identify the wage level effect of mobility. In contrast to these authors, however, we do not restrict our analysis to the wage effects for migrants to or out of metropolitan areas, but rather study movers between other types of regions as well. This enables us to differentiate between a general effect of inter-regional mobility and a specific effect being tied to metropolitan areas as the region of destination. The existence of a significant general effect would reduce the magnitude of the rural-tourban migration wage premium found by these authors.

The remainder of the paper is organized as follows: The next section deals with a description of our data source, methodological issues and basic definitions. Section 3 presents some descriptive evidence. Section 4 introduces our econometric model. By using a decomposition technique, the migration wage differential is analyzed in section 5. Section 6 checks the robustness of our results using alternative empirical strategies and section 7 concludes. 


\section{Data and basic definitions}

\subsection{Data}

The data used in this paper is a one percent random sample from the employment register of the Institute of Employment Research, Nuremberg (IAB). The data base (IABREG) contains all workers, employees and trainees with the obligation of paying social insurance contributions and represents about 80 percent of the total workforce. Not included in the data are, for instance, civil servants, marginal employed persons, students enrolled in higher education, workers under apprenticeship, volunteers and family workers. The employment register contains detailed histories for each worker's time in employment. Here we consider all persons aged 16 to 70 years who were employed on $30^{\text {th }}$ June of each year. The key variable for our analysis is gross daily wages ${ }^{5}$ being gathered in the register for administrative purposes. Due to legal sanctions for the employer in cases of misreporting, the variable can be considered highly reliable. Because of the contribution assessment ceiling in the German social security system, however, the earnings information is top coded. This concerns less than 10 percent of all observations. The likelihood of censoring increases with age and education. Moreover, the data set gives information on personal characteristics of workers like gender, age and education as well as some basic information about the employer (industry affiliation, location, firm size).

In our analysis the qualification of workers will be subdivided into three categories:

- low-skilled: persons with no occupational qualification regardless of which schooling level, that is, with or without upper secondary education (Abitur);

- skilled: persons with an occupational qualification whether they have an upper secondary education or not;

- highly-skilled: persons with upper secondary education holding a university degree or higher education diploma.

The regional information in the data refers to the location of the firm or workplace and not the residence of a worker. Using a classification scheme of the Bundesanstalt für Bauwesen und Raumordnung (BBR) we differentiate between nine types of regions at NUTS3 (county) level. The classifica- 
tion scheme of the BBR distinguishes between areas with large agglomerations, areas with features of conurbation and areas of rural character. Within areas comprising large agglomerations, the classification scheme distinguishes between metropolitan core cities (BBR1), highly urbanized districts (BBR2) in the surroundings of those cities, urbanized districts (BBR3) and rural districts (BBR4). The second category contains core cities (BBR5) in regions with intermediate agglomerations, their urbanized surroundings (BBR6) and rural districts (BBR7). In the regions of rural character the differentiation is between urbanized districts (BBR8) and rural districts (BBR9). ${ }^{6}$ The firm size information in the data is divided into eight categories (see Appendix, table A2).

Because there are still large structural differences in the labour market and the mobility pattern between the eastern and the western part of Germany ${ }^{7}$, we restrict the analysis to workers in pre-unified Germany. Beyond this we drop part-time workers, workers with more than one job and those for whom we have no valid information concerning earnings, age, qualification or the region type they work in (see Appendix, table A3 for data selection).

\subsection{Basic definitions}

Following GLAESER and MARÈ (2001) we concentrate on the spatial dimension of mobility. Like these authors our approach stresses the role of the characteristics of regions for wage determination in order to catch possible agglomeration effects. Throughout the paper we therefore define mobility of employed workers as a change in the BBR-region type where the workplace is located. ${ }^{8}$ We disregard workers who are not observed at the cut-off date for two succeeding years. Hence we exclude observations of mobile workers who were not employed in period $t=0$, but employed in $t=1$ ("drop-ins"), those who were employed in period $t=0$, but not in $t=1$ ("drop-outs"), and, of course, those who were unemployed or out of the labour force for both periods. We construct a $(0,1)$-dummy variable that indicates whether or not a person is employed in a different type of region in period $t=1$. In $t=0$ those who are going to reveal their mobility in the next period are called future movers (FM). After having moved to a workplace in a different region type, this group of workers is addressed in period $t=1$ as current movers (CM), or simply movers. Correspondingly, workers who do not change the type of region 


\section{Basic facts about movers and stayers}

\subsection{The mover/ stayer-wage differential}

Figure 1 shows the raw wage differential of movers over stayers and a 95 percent confidence interval for 1991 to 1997. It turns out that the differential varies to some extent but is positive in all years. The differential is lowest ( 0.3 percent) and statistically not significant in the re-unification boom year 1992 and highest in 1996 (3.8 percent). The average value is about 2 percent and there appears to be no clear time trend.

\section{+++++ Insert Figure 1 about here +++++}

Comparing the average wage of mobile and immobile workers before migration gives a completely different picture. As shown in figure 2, the corresponding wage differential of prospective movers is negative. This indicates that mobile workers have a wage disadvantage in the year before migration compared to their immobile counterparts. The differential is especially high in the early nineties, where the corresponding raw wage differential reaches almost -7 percent. Between 1993 and 1996 the raw differential is in the range of -1.5 to -2.5 percent. Assuming that differences in personal characteristics between the group of movers and stayers are stable over time, one can combine the information contained in figure 1 and 2 to conclude that moving entails a positive wage effect. Since movers can substantially improve their relative wage position immediately after getting a workplace in a dif- 
ferent type of region, there is first evidence of a general "wage level" effect of mobility. At this stage of analysis, however, it is not clear whether prospective movers are "underpaid" before moving and try to offset their disadvantage by mobility, or exhibit characteristics that are responsible for a lower wage. The negative wage effect before moving might also be due to the famous Ashenfelter dip (see ASHENFELTER, 1978). This would indicate that workers reduce their search effort in the region of origin because the migration decision has already been taken.

+++++ Insert Figure 2 about here +++++

\subsection{Differences in the characteristics of movers and stayers}

Up to now the raw wage differential of movers and stayers was considered without taking possible differences in observed characteristics of these groups into account. In order to present some basic information on these differences we have chosen the year 1997. ${ }^{9}$

With respect to gender, it can be seen from table 2 that more than 71 percent of all movers are male workers, while the share of male workers in the reference group of stayers is less than 67 percent. The corresponding over-representation of male workers in the group of movers is also reflected by the measure of concentration. ${ }^{10}$ As can be expected by migration theory, movers and stayers also differ in their skills. Compared to the reference group, movers are more likely to be skilled (77.8 percent versus 75.0 percent) or highly-skilled (11.3 percent versus 7.9 percent) as shown in table $2 .{ }^{11}$ These discrepancies are mirrored by a large difference of shares in the low-skilled category (10.8 percent versus 17.1 percent).

+++++ Insert Table 2 about here +++++

Further aspects concern the workers' potential on-the-job experience ${ }^{12}$, the region type and firm size. Here we consider three experience, four region type and three firm size categories. ${ }^{13}$ Table 2 shows that movers are distinctly less experienced than stayers: 28.5 percent of movers have less than 10 years' potential work experience, while the share of stayers in that low experience category is 18.6 percent only. In the intermediate experience category (10 to 19 years) the share of movers exceeds that of stayers by about 7 percentage points, while the share of movers with high experience is 32.3 percent 


\section{Econometric estimates based on earnings functions}

\subsection{Outline of the estimation approach}

In order to analyze the wage differential between mobile and immobile workers more rigorously we estimate a Mincer-type wage equation for each of the four groups defined above. ${ }^{15}$ More specifically, for each group we assume a linear relationship between the log earnings and several explanatory variables measuring skill, (potential) experience and other characteristics of the worker and the employer. Potential experience ( $E X P)$ enters the wage equation in linear and quadratic form to capture a nonlinear (concave) wage/ experience profile. We measure the effect of six skill/ gender categories by corresponding $(0,1)$-dummy variables, where $\operatorname{DSKILL}_{n}(n=1, \ldots, 3)$ indicate male workers with low, intermediate and high skills, respectively, while $\operatorname{DSKILL}_{n}(n=4, \ldots, 6)$ stand for the corresponding three skill categories of female workers. The effect of firm size on earnings is captured by eight differ- 
entiated firm-size $(0,1)$-dummy variables $($ FIRMSIZE) with the smallest category (less than 6 workers) chosen as a reference. ${ }^{16}$ In addition, our estimation approach includes eight $(0,1)$-dummy variables for the type of region (REGIONTYPE) taking metropolitan cities (BBR1) as the reference category. Moreover, we introduce interaction effects between the workers' experience with gender and qualification $^{17}$. The equation to be estimated can be formulated as

$$
\begin{aligned}
\ln w_{i}^{\theta} & =\alpha_{0}^{\theta}+\alpha_{1}^{\theta} E X P_{i}+\alpha_{2}^{\theta} E X P_{i}^{2}+\alpha_{3, n}^{\theta} \sum_{n=2}^{8} \operatorname{FIRMSIZE}_{n, i}+\alpha_{4, n}^{\theta} \sum_{n=2}^{9} \operatorname{REGIONTYPE}_{n, i} \\
& +\alpha_{5, n}^{\theta} \sum_{n=2}^{6} \operatorname{DSKILL}_{n, i} \\
& + \text { interactions of experience and experience squared } \\
& \text { with gender and qualification }+u_{i}^{\theta}
\end{aligned}
$$

The dependent variable $w_{i}^{\theta}$ stands for earnings of individual $i$ within a specific group of workers $\theta=\{C M, F M, C S, F S\}$. The error term $u_{i}^{\theta}$ is assumed to be independently and normally distributed. To account for top coding in the data, we use the Tobit estimation method.

\subsection{Estimation results}

Table 3 contains the results of the Tobit estimates for the successive years 1996 and $1997^{18}$. Sign and magnitude of the coefficients correspond to theoretical expectations. The Pseudo- $\mathrm{R}^{2}$ ranges between 0.38 and 0.43 and the standard error is about $1 / 3$ in all cases. The Likelihood-Ratio Test indicates a significant influence of the explanatory variables at the very high significance level. The number of observations is 3,899 for the group of movers whereof 386 observations or 9.9 percent are rightcensored in the year 1996, and 436 (11.2 percent) in 1997. For the group of stayers we have 152,999 observations including 14,453 right-censored observations in 1996 and 149,018 in 1997, thereof 13,895 right-censored.

+++++ Insert Table 3 about here +++++

With respect to the estimated coefficients we observe fairly similar results for the group of future and current movers on the one hand and future and current stayers on the other. There are, however, 


\section{Decomposition of the mover/ stayer-wage differential}

\subsection{Decomposition method}

Of course, the estimated coefficients of the dummy variables in eq.(1) depend on the choice of reference group. The coefficients would change, for example, if highly-skilled female workers were taken as the reference for the skill/ gender category instead of low-skilled male ones. Therefore, it is preferable to base the interpretation of the results on standardized coefficients that do not depend on the specific choice of the reference group. Following a method originally proposed by GREENE and SEAKS (1991), we therefore re-calculated the estimated coefficients in order to obtain effects relative to the weighted average in the aggregate economy. ${ }^{19}$ For the decompositions below we use the somewhat broader classifications as in Section 3.2. Considering six skill/ gender categories, four region types, three experience and firm size categories yields a total of $6 \times 4 \times 3 \times 3=216$ cells. The means 
of the explanatory variables are calculated for each cell. With this information and the estimated coefficients of the wage equations it is straightforward to compute the average wage for each cell as predicted by our model. We then use a BLINDER (1973)/ OAXACA (1973) technique for a groupspecific decomposition of the raw wage differential between movers and stayers. ${ }^{20}$

\subsection{Analysis of the mover/ stayer wage differential}

In order to investigate the net effect of work place mobility by comparing the wage of movers in the year after migration to the wage of their immobile counterparts in the region of destination, we consider decompositions by region type, skill category and experience. ${ }^{21}$ Table 4 contains the results at alternative levels of aggregation. Differentiation by region type only shows that earnings of movers and stayers vary substantially across types of regions. Immobile workers earn 6.8 percent above the national average in metropolitan regions (RT1), but 11.7 percent below in rural areas (RT4). While in metropolitan cities the spatial wage differential of movers is similar to that of stayers ( 6.1 percent), it differs markedly in region types with lower population density (RT2 and RT4). According to our estimates, earnings of immobile workers are well below the total average in RT2 ( -6.5 percent), while those of movers exceed the average by 1.5 percent. The corresponding values for stayers and movers in rural regions (RT4) are -11.7 and -3.5 percent respectively. At first glimpse the results seem to suggest that spatial wage differentials vary distinctly between mobile and immobile workers. However, these patterns might be strongly influenced by the characteristics of both groups.

+++++ Insert Table 4 about here +++++

Therefore, a deeper analysis requires the consideration of skill and experience categories for each type of region. We first take differences in the skill level into account. From the right panel of table 4 it is apparent that highly-skilled workers are clearly over-represented in core cities and their vicinities. Note that more than 10 percent of incumbent workers in RT1 are highly-skilled, while the corresponding share of the top skill category is distinctly lower in other region types (between 4 and 6 percent).

A closer inspection of table 4 shows that, irrespective of the region type, the share of movers belonging to the highest skill category exceeds that of stayers, while the opposite is true for low-skilled 
workers. At this level of differentiation, the estimated difference in movers' and stayers' earnings is predominantly negative in the urbanized regions (RT1 and RT3), and mostly positive in more rural ones (RT2 and RT4). Depending on the region type, the average earnings of low-skilled workers in the reference group of stayers are between 15 percent and 30 percent below the total average. For the intermediate skill category we find earnings between 9 percent below and 5 percent above the average. By contrast, the earnings of the highly-skilled are between 40 and 54 percent above average. Thus the wage advantage of movers over stayers tends to increase with the skill level. This is in accordance with theoretical predictions.

The finest form of decomposition is obtained by additionally considering experience. Differentiating by experience turns out to be crucial for understanding the effects of moving on wages. Except for highly experienced low-skilled workers, movers to RT2, RT3 and RT4 are always better off than their immobile counterparts. Somewhat surprisingly, we generally find the highest migration wage differentials for young low-skilled workers. ${ }^{22}$ Of special interest are the effects in RT1. Low-skilled migrants to this region type exhibit a marked disadvantage with respect to the incumbent workforce if they belong to the intermediate or high-experience category. By contrast, all categories of highly-skilled migrants immediately receive relative wage gains. ${ }^{23}$ This result is at odds with the findings of GLAESER and MARÈ (2001). Their general result that movers to metropolitan areas earn less than the stayers is not supported by the evidence here.

\subsection{Comparing decomposition results at different levels of aggregation}

Table 5 gives an overview for the decomposition results at different levels of aggregation. At the highest level we differentiate between region types only (model 1). We then add successively the dimensions gender (model 2), skill (model 3) and experience (model 4). In model 5, the most comprehensive model, all explanatory variables of the estimated equation are considered (region type/ skill/ gender/ experience and firm size). Note that for all models the rewards, characteristics and interaction effects sum up to the total effect of 2.55 .

+++++ Insert Table 5 about here +++++ 
In model 1 we observe that the rewards effect clearly dominates the characteristics effect. Including the gender dimension in model 2 yields a positive characteristics effect (1.9 percent). This is due to the over-representation of male workers in the group of movers. Taking the qualification of workers into account (model 3) reinforces the characteristics effect since movers are more skilled on average than immobile workers. So far, however, an important negative wage-determining factor in the typical characteristics of movers -their low level of experience- has been neglected. Hence, model 3 overstates the characteristics effect, which is mirrored by a strongly negative deviation in the rewards effect. As shown by model 4, controlling for experience reduces the characteristics effect considerably (from 4.5 to 1.5 percent). Consideration of firm size adds a further negative component to the characteristics effect (model 5). The reason for this lies in the fact that movers tend to work in smaller firms than stayers. As can be concluded from the most comprehensive model, movers have less favourable characteristics in total than stayers. Hence, the positive overall effect of mobility cannot be explained by observed characteristics.

\section{Robustness checks}

\subsection{Unobserved heterogeneity}

An objection against the earnings-function approach used so far is that the results could possibly be biased because of the neglect of unobserved heterogeneity. Mobile and immobile workers, for instance, might differ in their career attitudes, working behaviour and other related factors that we cannot directly observe. Hence, the positive earnings effects attributed to interregional mobility might actually be due to this hidden information. A well-known approach for taking account of the timeinvariant part of unobserved heterogeneity is the fixed-effects model. Using data for 1996 and 1997 we ran a fixed-effects version of the earnings-function approach described in Section 4, where the time invariant explanatory variables were dropped. According to the results shown in table 6, the wage growth of movers exceeds that of observationally equivalent stayers by about 1.7 percentage points with a t-statistic of 7.85 . Hence the results of a wage advantage of movers over stayers survive the consideration of time-invariant unobserved heterogeneity of workers. ${ }^{24}$ 


\subsection{Propensity score matching}

To deal with the selectivity issue, one could alternatively use a matching approach. ${ }^{25}$ The idea is that the best estimate of the outcome variable for (untreated) individuals of a specific group is the outcome of individuals with observationally equivalent characteristics in a reference group.

Let $W_{0}$ and $W_{1}$ denote two random variables for earnings of immobile or mobile workers, respectively, and $D \in\{0,1\}$ be a dummy variable indicating whether a person belongs to the group of stayers $(D=0)$ or the group of movers $(D=1)$. Furthermore, define $X$ as a vector of characteristics. The impact of migration on earnings for a mobile worker with (observable) characteristics $X_{i}$ is the difference between the expected outcome of a mover with these characteristics, $\mathrm{E}\left(W_{1 i} \mid D_{i}=1, X=X_{i}\right)$, and the hypothetical situation that this individual would have expected had she or he stayed in the region of origin $\mathrm{E}\left(W_{0 i} \mid D_{i}=1, X=X_{i}\right)$. The problem is to find a suitable estimate for the latter expression which is not observable. The basic idea of the potential outcome approach ${ }^{26}$ is to replace the counterfactual with the observed outcome of an individual (or individuals) from the control group with ideally identical characteristics. With highly differentiated characteristics, however, finding exact matches is hardly possible even in large data sets. To circumvent the curse of dimensionality the comparison is based on similar rather than on identical individuals. As a measure of similarity we choose the propensity score $\operatorname{Pr}\left(D_{i} \mid X=X_{i}\right)$ of a probit regression that describes the selection of individual $i$ into the treatment group. ${ }^{27}$ There are several possibilities for constructing the counter-factual. A simple one is the $n$-nearest neighbour method which uses the $n$ observations in the control group most similar to an individual in the "treatment group", i.e. here, in the group of mobile workers. A more sophisticated approach uses all observations of the control group but attaches weights to them which are lower the more distant the observation is from the observation in the treatment group. These weights are calculated using a kernel estimate of the distribution. 
In the probit regression we used all characteristics of workers as described in Section $4 .{ }^{28}$ The selection into future movers and stayers is modelled using characteristics of 1996, i.e. the year before migration. For determining the wage effect of mobility one could either compare movers with stayers in the region of destination or with stayers in the region of origin. For the first (second) alternative one has to use 1997 (or 1996, respectively) characteristics in order to identify the corresponding matches between movers and stayers. For the construction of the counter-factual we analysed the first nearest neighbour approach and kernel matching as two extreme cases. It turns out, however, that both alternative matching methods produce similar results. The standard errors were generated by bootstrapping (see, e.g. HECKMAN et al., 1998).

In analogy to the fixed-effects method, the matching approach can also be based on wage growth rates rather than on levels. In the empirical literature on programme evaluation (see, for example, HECKMAN et al., 1999; SMITH and TODD, 2005) it is assumed that the impact of unobservable characteristics on the outcome is constant over time. Under this assumption, unobserved heterogeneity is differenced out by using difference-in-differences matching. In our empirical application we considered this as a further alternative.

The results for the different variants of the matching approach are given in table 7. Comparing an unmatched selection of movers and stayers in the year before migration confirms the result in figure 2, showing that future movers have a wage disadvantage against future stayers. Matching reduces the wage differential markedly in case of the nearest neighbour method (where it becomes statistically insignificant) and less so in the case of kernel matching. This finding suggests that less favourable characteristics of movers are at least partly responsible for lower wages in the year before moving. ${ }^{29}$

+++++ Insert Table 7 about here +++++

In the year after migration the average treatment effect on the treated is about 2.6 percent for both methods of constructing the counterfactual. This is in accordance with the 2.55 percent wage differential we found using the earnings function approach. Thus, the results of the matching procedure based on (log) wage levels of movers and stayers support the findings documented in Section 5. 


\section{Conclusions}

The aim of this paper was to investigate the general and group-specific effects of interregional mobility on earnings. We find that in the year before workers migrate they have distinctly lower mean earnings than their immobile colleagues. After migration, the average mobile worker typically catches up with the average stayer in the region of destination or even experiences higher wages. This is the case although movers tend to have less favourable characteristics than stayers. Hence, labour mobility leads to a wage gain relative to stayers in the region of destination that cannot be attributed to observed characteristics.

One should stress that the overall characteristics effect of movers is the result of strong opposing forces. On the positive side, movers are typically more skilled. The fact that males are overrepresented in the group of movers also contributes to higher mean earnings. On the negative side, mobile workers are younger, i.e. less experienced than their immobile counterparts. Compared to stay- 
ers, a further structural disadvantage of movers is that they are more likely to work in smaller firms. This aspect has been neglected in most of the literature concerning the migration wage differential.

It is interesting to compare our results with those of GLAESER and MARÈ (2001). These authors find wage gains for movers to metropolitan areas because of a wage level effect due to the urban environment. Compared to the incumbent workforce in these areas, however, the earnings of movers fall behind. Their explanation of this phenomenon is that the impact of favourable agglomeration forces becomes fully effective only after a certain period of time. Our results are at least partly at odds with these findings. The evidence in the present paper indicates that earnings of several groups of movers even surpass those of the incumbent workforce in core cities. All in all, our results support the hypothesis that the wage level effect is not uniform across different groups of workers (as was implicitly assumed in the approach chosen by GLAESER and MARÈ (2001)). Moreover, GLAESER and MARÈ (2001) do not consider the effect of moving between non-metropolitan areas. Therefore, they are not able to detect a positive effect of mobility independent of urban influences. Our empirical evidence supports the hypothesis of a general effect. The estimation results presented indicate that the post-migration wage differential is positive for most groups of workers irrespective of the region of destination. Hence, it is at least questionable whether the wage level effect is fully caused by the urban environment. Our findings corroborate the view that the gains from mobility mainly stem from the actual decision to migrate.

Checking the robustness of the general results, we employ a fixed-effects model and several variants of a matching approach.Irrespective of the method used, the positive effects of mobility are in the order of magnitude of 2 to 3 percent and statistically highly significant. We conclude that the positive impact of inter-regional mobility on earnings is not an artefact generated by differences in either observed or unobserved characteristics of movers and stayers as long as the latter are confined to being time-invariant. 
1

2

Acknowledgements - We are grateful to two anonymous referees for valuable suggestions for improving the paper. We would also like to thank the participants of a session on regional labour markets at the annual meeting of the German Economic Association (Verein für Socialpolitik) and Alisher Aldashev for very helpful comments. We alone are responsible for any remaining errors. Financial support from the German Science Foundation (Deutsche Forschungsgemeinschaft, Projekt MO 523/ 32) is gratefully acknowledged. 


\section{Appendix}

\section{Description of the decomposition technique}

Let the usual wage equation for mobile and immobile workers be given as $\mathbf{y}=\mathbf{x}^{\prime} \beta+\varepsilon$ and $\mathbf{Y}=\mathbf{X}^{\prime} \mathbf{B}+\mathbf{E}$ respectively. Then define $\Delta \hat{\boldsymbol{\beta}}:=\hat{\boldsymbol{\beta}}-\hat{\mathbf{B}}$ and $\Delta \overline{\mathbf{x}}:=\overline{\mathbf{x}}-\overline{\mathbf{X}}$, where the vectors $\overline{\mathbf{x}}$ and $\overline{\mathbf{X}}$ contain average values of the explanatory variables for movers and stayers respectively. The decomposition of the raw earnings differential $\overline{\mathbf{y}}-\overline{\mathbf{Y}}$ can be obtained as

$$
\begin{aligned}
& \begin{aligned}
& \bar{y}-\bar{Y}:=\overline{\mathbf{x}} \hat{\boldsymbol{\beta}}-\overline{\mathbf{X}} \hat{\mathbf{B}} \\
&=\underbrace{\overline{\mathbf{X}} \cdot \Delta \hat{\boldsymbol{\beta}}}_{\text {evaluation effect }}+\underbrace{\Delta \overline{\mathbf{x}} \cdot \hat{\mathbf{B}}}_{\begin{array}{c}
\text { characteristics } \\
\text { effect }
\end{array}}+\underbrace{\Delta \overline{\mathbf{x}} \cdot \Delta \hat{\boldsymbol{\beta}}}_{\begin{array}{c}
\text { interaction } \\
\text { effect }
\end{array}} \\
&+++++ \text { Insert Table A1 here }+++++ \\
&+++++ \text { Insert Table A2 here }+++++
\end{aligned} \\
& +++++ \text { Insert Table A3 here }+++++
\end{aligned}
$$


Table 1:

Absolute Number and Share of Movers and Stayers in the Sample (1991-1997)

\begin{tabular}{|l|ccccccc|}
\hline & $\mathbf{1 9 9 1}$ & $\mathbf{1 9 9 2}$ & $\mathbf{1 9 9 3}$ & $\mathbf{1 9 9 4}$ & $\mathbf{1 9 9 5}$ & $\mathbf{1 9 9 6}$ & $\mathbf{1 9 9 7}$ \\
\hline total & 174,337 & 174,734 & 169,659 & 163,949 & 161,302 & 156,898 & 152,917 \\
stayers & 169,160 & 169,825 & 165,351 & 159,773 & 157,203 & 152,894 & 149,018 \\
percent of total & 97.0 & 97.2 & 97.5 & 97.5 & 97.5 & 97.4 & 97.5 \\
movers & 5,177 & 4,909 & 4,308 & 4,176 & 4,099 & 4,004 & 3,899 \\
percent of total & 3.0 & 2.8 & 2.5 & 2.5 & 2.5 & 2.6 & 2.5 \\
\hline
\end{tabular}

Notes: The entries in the table are calculated on the basis of a 1-percent sample. Source: Authors' own calculations using IAB-REG data. 

Absolute Number and Share of Movers and Stayers by Skills,
Firm Size and Region Type (1997)

\begin{tabular}{|c|c|c|c|c|c|}
\hline & \multicolumn{2}{|c|}{ Stayers } & \multicolumn{3}{|c|}{ Movers } \\
\hline & $\begin{array}{l}\text { Absolute } \\
\text { Number }\end{array}$ & Share & $\begin{array}{l}\text { Absolute } \\
\text { Number }\end{array}$ & Share & $\begin{array}{c}\text { Measure of } \\
\text { Concentration }\end{array}$ \\
\hline \multicolumn{6}{|c|}{ gender } \\
\hline male & 99,637 & 0.669 & 2,799 & 0.718 & 107.2 \\
\hline female & 49,381 & 0.331 & 1,100 & 0.282 & 85.4 \\
\hline total & 149,018 & 1 & 3,899 & 1 & 100 \\
\hline \multicolumn{6}{|c|}{ skills } \\
\hline low-skilled & 25,508 & 0.171 & 423 & 0.108 & 63.98 \\
\hline skilled & 111,736 & 0.75 & 3,034 & 0.778 & 103.68 \\
\hline highly-skilled & 11,774 & 0.079 & 442 & 0.113 & 141.9 \\
\hline total & 149,018 & 1 & 3,899 & 1 & 100 \\
\hline \multicolumn{6}{|c|}{ experience } \\
\hline low exp. & 27,661 & 0.186 & 1,110 & 0.285 & 151.31 \\
\hline med. exp. & 47,647 & 0.32 & 1,530 & 0.392 & 122.02 \\
\hline high exp. & 73,710 & 0.495 & 1,259 & 0.323 & 65.86 \\
\hline total & 149,018 & 1 & 3,899 & 1 & 100 \\
\hline \multicolumn{6}{|c|}{ firm size } \\
\hline small firm size & 55,260 & 0.371 & 1,775 & 0.455 & 122.06 \\
\hline med. firm size & 53,872 & 0.362 & 1,440 & 0.369 & 102.1 \\
\hline large firm size & 39,886 & 0.268 & 684 & 0.175 & 66.12 \\
\hline total & 149,018 & 1 & 3,899 & 1 & 100 \\
\hline \multicolumn{6}{|c|}{ region type } \\
\hline RT 1 & 74,809 & 0.502 & 2,014 & 0.517 & 102.82 \\
\hline RT 2 & 11,570 & 0.078 & 412 & 0.106 & 134.86 \\
\hline RT 3 & 36,774 & 0.247 & 931 & 0.239 & 96.84 \\
\hline RT 4 & 25,865 & 0.174 & 542 & 0.139 & 80.5 \\
\hline total & 149,018 & 1 & 3,899 & 1 & 100 \\
\hline
\end{tabular}

Notes: Authors' own calculations using IAB-REG; measure of concentration: 100 *share of movers of this category in total movers divided by the share of movers and stayers of this category in total workers. 
Table 3:

Results of the Wage Equation Estimates for Future and Current Movers and Stayers (1996/ 1997)

\begin{tabular}{|c|c|c|c|c|c|c|c|c|}
\hline \multirow[b]{3}{*}{ Variable } & \multicolumn{4}{|c|}{1996} & \multicolumn{4}{|c|}{1997} \\
\hline & \multicolumn{2}{|c|}{$\begin{array}{l}\text { Future movers } \\
\text { (FM) }\end{array}$} & \multicolumn{2}{|c|}{$\begin{array}{c}\text { Future stayers } \\
\text { (FS) }\end{array}$} & \multicolumn{2}{|c|}{$\begin{array}{l}\text { Current movers } \\
\text { (CM) }\end{array}$} & \multicolumn{2}{|c|}{$\begin{array}{c}\text { Current stayers } \\
\text { (CS) }\end{array}$} \\
\hline & Coef. & Std. Err. & Coef. & Std. Err. & Coef. & Std. Err. & Coef. & Std. Err. \\
\hline \multicolumn{9}{|l|}{ Low-skilled male (ref.) } \\
\hline Skilled male & 0.080 & 0.065 & 0.265 & 0.010 & 0.085 & 0.073 & 0.311 & 0.011 \\
\hline Highly-skilled male & 0.540 & 0.067 & 0.711 & 0.011 & 0.588 & 0.075 & 0.765 & 0.011 \\
\hline Low-skilled female & -0.178 & 0.052 & -0.036 & 0.008 & -0.143 & 0.056 & -0.023 & 0.008 \\
\hline Skilled female & -0.013 & 0.072 & 0.209 & 0.011 & -0.005 & 0.081 & 0.265 & 0.012 \\
\hline Highly-skilled female & 0.328 & 0.079 & 0.581 & 0.013 & 0.399 & 0.088 & 0.647 & 0.014 \\
\hline \multicolumn{9}{|l|}{ Firm size: $<=5$ workers (ref.) } \\
\hline Firm size: $6-20$ workers & 0.129 & 0.021 & 0.211 & 0.004 & 0.111 & 0.020 & 0.218 & 0.004 \\
\hline Firm size: $21-50$ workers & 0.193 & 0.021 & 0.289 & 0.004 & 0.153 & 0.021 & 0.293 & 0.004 \\
\hline Firm size: $51-100$ workers & 0.202 & 0.023 & 0.341 & 0.004 & 0.176 & 0.022 & 0.345 & 0.004 \\
\hline Firm size: $101-250$ workers & 0.231 & 0.022 & 0.378 & 0.004 & 0.200 & 0.022 & 0.381 & 0.004 \\
\hline Firm size: $251-500$ workers & 0.306 & 0.025 & 0.419 & 0.004 & 0.247 & 0.024 & 0.427 & 0.004 \\
\hline Firm size: $501-1000$ workers & 0.279 & 0.027 & 0.443 & 0.004 & 0.291 & 0.027 & 0.455 & 0.004 \\
\hline Firm size: $>1000$ workers & 0.345 & 0.025 & 0.494 & 0.004 & 0.299 & 0.024 & 0.512 & 0.004 \\
\hline Firm size: missing & 0.270 & 0.072 & 0.232 & 0.015 & 0.140 & 0.053 & 0.154 & 0.023 \\
\hline \multicolumn{9}{|l|}{ Region type BBR 1 (ref.) } \\
\hline Region type BBR 2 & 0.019 & 0.016 & -0.015 & 0.003 & 0.050 & 0.015 & -0.009 & 0.003 \\
\hline Region type BBR 3 & -0.021 & 0.020 & -0.059 & 0.004 & 0.011 & 0.021 & -0.055 & 0.004 \\
\hline Region type BBR 4 & -0.068 & 0.038 & -0.082 & 0.007 & -0.030 & 0.044 & -0.076 & 0.007 \\
\hline Region type BBR 5 & -0.046 & 0.019 & -0.052 & 0.003 & -0.035 & 0.020 & -0.049 & 0.004 \\
\hline Region type BBR 6 & -0.042 & 0.018 & -0.070 & 0.003 & -0.013 & 0.018 & -0.062 & 0.003 \\
\hline Region type BBR 7 & -0.103 & 0.023 & -0.093 & 0.004 & -0.030 & 0.024 & -0.092 & 0.004 \\
\hline Region type BBR 8 & -0.045 & 0.025 & -0.107 & 0.003 & -0.026 & 0.024 & -0.103 & 0.004 \\
\hline Region type BBR 9 & -0.087 & 0.038 & -0.129 & 0.006 & -0.041 & 0.041 & -0.121 & 0.006 \\
\hline Experience & 0.018 & 0.007 & 0.031 & 0.001 & 0.018 & 0.007 & 0.035 & 0.001 \\
\hline Experience squared & -0.019 & 0.015 & -0.049 & 0.002 & -0.027 & 0.015 & -0.053 & 0.002 \\
\hline Interaction exp./ fem. & -0.005 & 0.005 & -0.016 & 0.001 & -0.005 & 0.005 & -0.016 & 0.001 \\
\hline Interaction exp. squared / fem. & -0.005 & 0.012 & 0.023 & 0.001 & -0.003 & 0.012 & 0.021 & 0.002 \\
\hline Interaction exp./qual. & 0.022 & 0.007 & -0.001 & 0.001 & 0.017 & 0.007 & -0.004 & 0.001 \\
\hline Interaction exp. squared/qual. & -0.044 & 0.016 & 0.000 & 0.002 & -0.032 & 0.016 & 0.004 & 0.002 \\
\hline Constant & 8.986 & 0.064 & 8.807 & 0.010 & 9.058 & 0.073 & 8.741 & 0.011 \\
\hline \multicolumn{9}{|c|}{ Test statistics } \\
\hline$N$ & 3,899 & & 152,999 & & 3,899 & & 149,018 & \\
\hline (thereof censored) & (386) & & $(14,453)$ & & (436) & & $(13,895)$ & \\
\hline Pseudo $\mathrm{R}^{2}$ & 0.410 & & 0.429 & & 0.382 & & 0.411 & \\
\hline $\operatorname{LR}\left[\chi^{2}(27)\right]$ & 2009.0 & & 82989.8 & & 1809.2 & & 79661.3 & \\
\hline s.e. & 0.330 & & 0.329 & & 0.329 & & 0.337 & \\
\hline
\end{tabular}

Notes: Estimation method is Tobit; all coefficients significant at least at the 5 percent level are in bold; all coefficients related to the experience squared variable are multiplied by 100 .

Source: Authors' own calculations using IAB-REG data. 
Table 4:

Estimated Wage Differential and Composition of the Workforce by Region Type, Skill and Experience (1997)

\begin{tabular}{|c|c|c|c|c|c|c|c|}
\hline & \multicolumn{3}{|c|}{$\begin{array}{l}\text { Wage differential } \\
\text { relative to the total average }\end{array}$} & \multicolumn{4}{|c|}{$\begin{array}{c}\text { Composition } \\
\text { (column shares in percent) }\end{array}$} \\
\hline & Movers & Stayers & Difference & Movers & & Stayers & Difference \\
\hline RT1 & 6.14 & 6.80 & -0.66 & 51.65 & & 50.20 & 1.45 \\
\hline low-skilled & -21.45 & -15.41 & -6.04 & 5.77 & & 8.57 & -2.80 \\
\hline low exp. & -30.60 & -40.02 & 9.42 & & & 0.77 & 0.11 \\
\hline med. exp. & -22.57 & -20.17 & -2.40 & & & 2.32 & -0.04 \\
\hline high exp. & -17.42 & -9.97 & -7.45 & & & 5.49 & -2.87 \\
\hline skilled & 2.48 & 5.06 & -2.58 & 39.27 & & 36.31 & 2.96 \\
\hline low exp. & -15.2 & -14.25 & -0.99 & & & 6.51 & 4.39 \\
\hline med. exp. & 2.87 & 3.00 & -0.12 & & & 11.65 & 3.23 \\
\hline high exp. & 16.36 & 13.31 & 3.05 & & & 18.15 & -4.66 \\
\hline highly-skilled & 51.94 & 54.47 & -2.53 & 6.62 & & 5.32 & 1.30 \\
\hline low exp. & 39.60 & 36.01 & 3.59 & & & 1.28 & 1.44 \\
\hline med. exp. & 57.22 & 53.71 & 3.51 & & & 2.08 & 0.79 \\
\hline high exp. & 69.86 & 67.36 & 2.50 & & & 1.96 & -0.93 \\
\hline RT2 & 1.52 & -6.51 & 8.03 & 10.57 & & 7.76 & 2.80 \\
\hline low-skilled & -26.33 & -26.16 & -0.17 & 1.13 & & 1.30 & -0.17 \\
\hline low exp. & -33.65 & -48.85 & 15.20 & & & 0.12 & 0.03 \\
\hline med. exp. & -24.83 & -30.75 & 5.92 & & & 0.37 & 0.27 \\
\hline high exp. & -25.8 & -20.65 & -5.19 & & & 0.81 & -0.47 \\
\hline skilled & -0.45 & -5.84 & 5.39 & 8.46 & & 6.05 & 2.42 \\
\hline low exp. & -17.8 & -25.05 & 7.20 & & & 1.26 & 1.05 \\
\hline med. exp. & 0.47 & -6.68 & 7.15 & & & 1.97 & 1.21 \\
\hline high exp. & 12.05 & 3.31 & 8.74 & & & 2.82 & 0.16 \\
\hline highly-skilled & 50.93 & 44.76 & 6.17 & 0.97 & & 0.42 & 0.56 \\
\hline low exp. & 32.00 & 24.60 & 7.40 & & & 0.10 & 0.23 \\
\hline med. exp. & 56.26 & 45.55 & 10.71 & & & 0.17 & 0.29 \\
\hline high exp. & 72.40 & 57.67 & 14.74 & & & 0.15 & 0.03 \\
\hline
\end{tabular}




\section{Table 4 (continued):}

\begin{tabular}{|c|c|c|c|c|c|c|c|c|c|}
\hline & \multicolumn{3}{|c|}{$\begin{array}{l}\text { Wage differential } \\
\text { relative to the total average }\end{array}$} & \multicolumn{6}{|c|}{$\begin{array}{c}\text { Composition } \\
\text { (column shares in percent) }\end{array}$} \\
\hline & Movers & Stayers & Difference & Mover & & Stayer & & Differe & nce \\
\hline RT3 & -1.49 & -3.81 & 2.31 & 23.88 & & 24.68 & & -0.80 & \\
\hline low-skilled & -28.86 & -23.97 & -4.89 & 2.44 & & 4.23 & & -1.79 & \\
\hline low exp. & -36.46 & -47.88 & 11.42 & & 0.54 & & 0.40 & & 0.14 \\
\hline med. exp. & -27.69 & -28.71 & 1.02 & & 0.80 & & 1.12 & & -0.32 \\
\hline high exp. & -26.00 & -18.47 & -7.53 & & 1.10 & & 2.71 & & -1.60 \\
\hline skilled & -4.84 & -3.31 & -1.53 & 18.77 & & 18.9 & & -0.18 & \\
\hline low exp. & -22.41 & -22.86 & 0.46 & & 5.95 & & 3.97 & & 1.98 \\
\hline med. exp. & -2.83 & -4.17 & 1.34 & & 7.31 & & 6.18 & & 1.13 \\
\hline high exp. & 11.45 & 6.11 & 5.34 & & 5.51 & & 8.80 & & -3.29 \\
\hline highly-skilled & 47.07 & 46.87 & 0.20 & 2.67 & & 1.50 & & 1.17 & \\
\hline low exp. & 34.05 & 28.97 & 5.08 & & 0.95 & & 0.37 & & 0.58 \\
\hline med. exp. & 50.15 & 46.15 & 4.00 & & 1.21 & & 0.60 & & 0.61 \\
\hline high exp. & 63.90 & 60.11 & 3.78 & & 0.51 & & 0.53 & & -0.02 \\
\hline RT4 & -3.53 & -11.72 & 8.19 & 13.90 & & 17.36 & & -3.46 & \\
\hline low-skilled & -27.96 & -30.95 & 2.99 & 1.51 & & 3.02 & & -1.51 & \\
\hline low exp. & -36.86 & -54.35 & 17.49 & & 0.10 & & 0.29 & & -0.19 \\
\hline med. exp. & -29.95 & -34.44 & 4.49 & & 0.59 & & 0.77 & & -0.18 \\
\hline high exp. & -25.42 & -26.09 & 0.67 & & 0.82 & & 1.96 & & -1.14 \\
\hline skilled & -4.91 & -9.99 & 5.08 & 11.31 & & 13.6 & & -2.36 & \\
\hline low exp. & -23.36 & -29.58 & 6.22 & & 3.21 & & 3.32 & & -0.12 \\
\hline med. exp. & -3.02 & -9.47 & 6.46 & & 4.57 & & 4.48 & & 0.09 \\
\hline high exp. & 9.37 & 0.72 & 8.65 & & 3.54 & & 5.87 & & -2.33 \\
\hline highly-skilled & 45.25 & 39.84 & 5.41 & 1.08 & & 0.67 & & 0.41 & \\
\hline low exp. & 31.55 & 20.36 & 11.19 & & 0.44 & & 0.17 & & 0.26 \\
\hline med. exp. & 50.55 & 41.25 & 9.30 & & 0.46 & & 0.27 & & 0.19 \\
\hline high exp. & 64.87 & 53.10 & 11.77 & & 0.18 & & 0.22 & & -0.04 \\
\hline Sum & & & & $100 \quad 100$ & 100 & $100 \quad 100$ & 100 & 0.000 .00 & $\mathbf{0 . 0 0}$ \\
\hline
\end{tabular}

Notes: Wage differential calculated from TOBIT estimates. Source: Authors' own calculations using IAB-REG data. 


\section{Table 5:}

Decomposition of the Mover/ Stayer Wage Differential at Different Levels of Aggregation (1997)

\begin{tabular}{|l|l|c|c|c|c|}
\hline Model & \multicolumn{1}{|c|}{ Explanatory variables } & $\begin{array}{c}\text { Evaluation } \\
\text { effect }\end{array}$ & $\begin{array}{c}\text { Character- } \\
\text { istics effect }\end{array}$ & $\begin{array}{c}\text { Interaction } \\
\text { effect }\end{array}$ & total \\
\hline 1 & Region type & 2.28 & 0.35 & -0.09 & \\
2 & Region type/ gender & 0.98 & 1.91 & -0.34 & \\
3 & Region type/ gender/ skill & -2.10 & 4.55 & 0.10 & \\
4 & Region type/ gender/ skill/ experience & 0.70 & 1.59 & 0.26 & \\
5 & Region type/ gender/ skill/ experience/ firm size & 2.35 & -1.01 & 1.21 & 2.55 \\
\hline
\end{tabular}

Source: Authors' own calculations using IAB-REG data. 
Source: Authors' own calculations using IAB-REG data. All coefficients significant at least at the 5 percent level are in bold.

\section{Table 6:}

Results of the Fixed Effect Estimates (1996/97)

\begin{tabular}{|l|cc|}
\hline Variable & Coef. & t-statistics \\
\hline Dummy 1997 & $\mathbf{0 . 0 6 0 2}$ & 47.44 \\
Region type BBR 1 (ref.) & & \\
Region type BBR 2 & $\mathbf{0 . 0 1 2 1}$ & 3.53 \\
Region type BBR 3 & 0.0055 & 1.08 \\
Region type BBR 4 & -0.0134 & -1.20 \\
Region type BBR 5 & -0.0026 & -0.49 \\
Region type BBR 6 & $\mathbf{- 0 . 0 1 3 8}$ & -2.93 \\
Region type BBR 7 & $\mathbf{- 0 . 0 2 0 8}$ & -3.17 \\
Region type BBR 8 & -0.0114 & -1.66 \\
Region type BBR 9 & 0.0061 & 0.54 \\
Age squared & $\mathbf{- 0 . 0 0 0 5}$ & -32.91 \\
Migration & $\mathbf{0 . 0 1 6 8}$ & 7.85 \\
Constant & $\mathbf{1 0 . 4 5 9 5}$ & 370.26 \\
\hline industry controls & \multicolumn{2}{|c|}{ included } \\
firm size controls & 33.29 \\
\hline \multicolumn{2}{|c|}{ Test statistics } \\
\hline F (137064, 134744) & \multicolumn{2}{|c|}{} \\
\hline
\end{tabular}


Table 7:

Results from Nearest Neighbour and Kernel Matching

\begin{tabular}{|c|c|c|c|c|}
\hline \multicolumn{5}{|c|}{ Level approach, outcome variable: wage } \\
\hline & $\begin{array}{l}\text { future } \\
\text { movers }\end{array}$ & controls & ATET & z-value \\
\hline \multicolumn{5}{|c|}{1996} \\
\hline Unmatched & 149.86 & 152.26 & -1.59 & - \\
\hline Nearest neighbour matching & 149.86 & 150.00 & -0.09 & -0.09 \\
\hline \multirow[t]{2}{*}{ Kernel matching } & 149.86 & 151.75 & -1.25 & $-2.29 *$ \\
\hline & movers & controls & ATET & z-value \\
\hline \multicolumn{5}{|c|}{1997} \\
\hline Unmatched & 157.40 & 153.70 & 2.38 & - \\
\hline Nearest neighbour matching & 157.40 & 153.28 & 2.65 & $2.51^{*}$ \\
\hline Kernel matching & 157.40 & 153.33 & 2.62 & $3.52 * *$ \\
\hline \multicolumn{5}{|c|}{$\begin{array}{l}\text { Difference-in-differences approach, outcome variable: } \\
\text { wage growth (in \%) }\end{array}$} \\
\hline 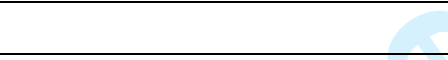 & movers & controls & ATET & z-value \\
\hline \multicolumn{5}{|c|}{$1996 / 1997$} \\
\hline Unmatched & 4.96 & 2.03 & 2.93 & - \\
\hline Nearest neighbour matching & 4.96 & 2.42 & 2.54 & $4.79 * *$ \\
\hline Kernel matching & 4.96 & 2.13 & 2.83 & $4.83^{* *}$ \\
\hline
\end{tabular}

Notes: $* * * *$ indicates statistical significance at the $1 \%$ level and $5 \%$ level. $\mathrm{z}$-values are calculated by using a bootstrap method (300 replications for Nearest Neighbour Matching and 50 replications for Kernel Matching). The average treatment effect on the treated (ATET) is measured as log wage differential. Wages are calculated from log earnings. The probit regression is based on skill/ gender, experience, firm size and region type variables. In case of Kernel Matching the bandwidth is 0.06 (Stata standard). The presented results are robust with respect to the choice of the bandwidth.

Source: Authors' own calculations based on IAB-REG. 


\section{Table 8:}

Results From Nearest Neighbour Matching Using 1996 Characteristics

\begin{tabular}{|c|c|c|c|c|}
\hline \multicolumn{5}{|c|}{ Level approach, outcome variable: wage } \\
\hline & movers & controls & ATET & z-value \\
\hline \multicolumn{5}{|c|}{1997} \\
\hline Nearest neighbour matching & 157.40 & 153.77 & 2.33 & $2.14^{*}$ \\
\hline \multicolumn{5}{|c|}{$\begin{array}{l}\text { Difference-in-differences approach, outcome variable: } \\
\text { wage growth (in \%) }\end{array}$} \\
\hline & movers & controls & ATET & z-value \\
\hline \multicolumn{5}{|c|}{$1996 / 1997$} \\
\hline Nearest neighbour matching & 4.91 & 2.63 & 2.28 & $4.61^{* *}$ \\
\hline
\end{tabular}

Notes: The probit regression is based on skill/ gender, experience, firm size and region type, log wages and industry variables in 1996. For further notes see table 7. 


\section{Table A1: Regional Classification Scheme Based on BBR-Classification}

\begin{tabular}{|c|c|c|c|}
\hline Structural region type & $\begin{array}{l}\text { District type (BBR- } \\
\text { Classification) }\end{array}$ & $\begin{array}{l}\text { Region types (RT) } \\
\text { used in the paper }\end{array}$ & Description of region type (BBR) \\
\hline \multirow{4}{*}{$\begin{array}{l}\text { Regions with large ag- } \\
\text { glomerations }\end{array}$} & BBR1 & RT1 & Core cities \\
\hline & BBR2 & RT1 & $\begin{array}{l}\text { Highly urbanized districts in regions } \\
\text { with large agglomerations }\end{array}$ \\
\hline & BBR3 & RT2 & $\begin{array}{l}\text { Urbanized districts in regions with } \\
\text { large agglomerations }\end{array}$ \\
\hline & $\overline{\text { BBR4 }}$ & RT2 & $\begin{array}{c}\text { Rural districts in regions with large } \\
\text { agglomerations }\end{array}$ \\
\hline \multirow{3}{*}{$\begin{array}{l}\text { Regions with features of } \\
\text { conurbation }\end{array}$} & BBR5 & RT3 & $\begin{array}{l}\text { Central cities in regions with inter- } \\
\text { mediate agglomerations }\end{array}$ \\
\hline & BBR 6 & RT3 & $\begin{array}{l}\text { Urbanized districts in regions with } \\
\text { intermediate agglomerations }\end{array}$ \\
\hline & BBR 7 & RT4 & $\begin{array}{l}\text { Rural districts in regions with inter- } \\
\text { mediate agglomerations }\end{array}$ \\
\hline \multirow{2}{*}{$\begin{array}{l}\text { Regions of rural charac- } \\
\text { ter }\end{array}$} & BBR8 & RT4 & Urbanized districts in rural regions \\
\hline & BBR9 & RT4 & Rural districts in rural regions \\
\hline
\end{tabular}


Table A2: Classification of the Firm Size

\begin{tabular}{|c|c|c|}
\hline $\begin{array}{l}\text { Firm size } \\
\text { categories }\end{array}$ & $\begin{array}{l}\text { Aggregated firm size } \\
\text { categories }\end{array}$ & $\begin{array}{c}\text { Number of } \\
\text { workers }\end{array}$ \\
\hline FS1 & \multirow{3}{*}{ small } & $1-5$ \\
\hline $\mathrm{FS} 2$ & & $6-20$ \\
\hline FS3 & & $21-50$ \\
\hline FS4 & \multirow{3}{*}{ medium } & $51-100$ \\
\hline FS5 & & $101-250$ \\
\hline FS6 & & $251-500$ \\
\hline FS7 & \multirow{2}{*}{ large } & $501-1000$ \\
\hline FS8 & & $>1000$ \\
\hline
\end{tabular}


Table A3: Selection of Data (1996/ 1997)

\begin{tabular}{|l|c|}
\hline & $\begin{array}{c}\text { number } \\
\text { of cases }\end{array}$ \\
\hline total number of individual observations & 535,578 \\
\hline West Germany (old laender) only & 432,663 \\
\hline multiple employed workers excluded & 428,579 \\
\hline with valid earnings information & 416,334 \\
\hline workers under apprenticeship, volunteers, family workers excluded & 392,986 \\
\hline with valid information about age, qualification and place of work & 359,795 \\
\hline part-time workers excluded & 309,815 \\
\hline & \\
\hline Observations used in our sample & 309,815 \\
\hline
\end{tabular}




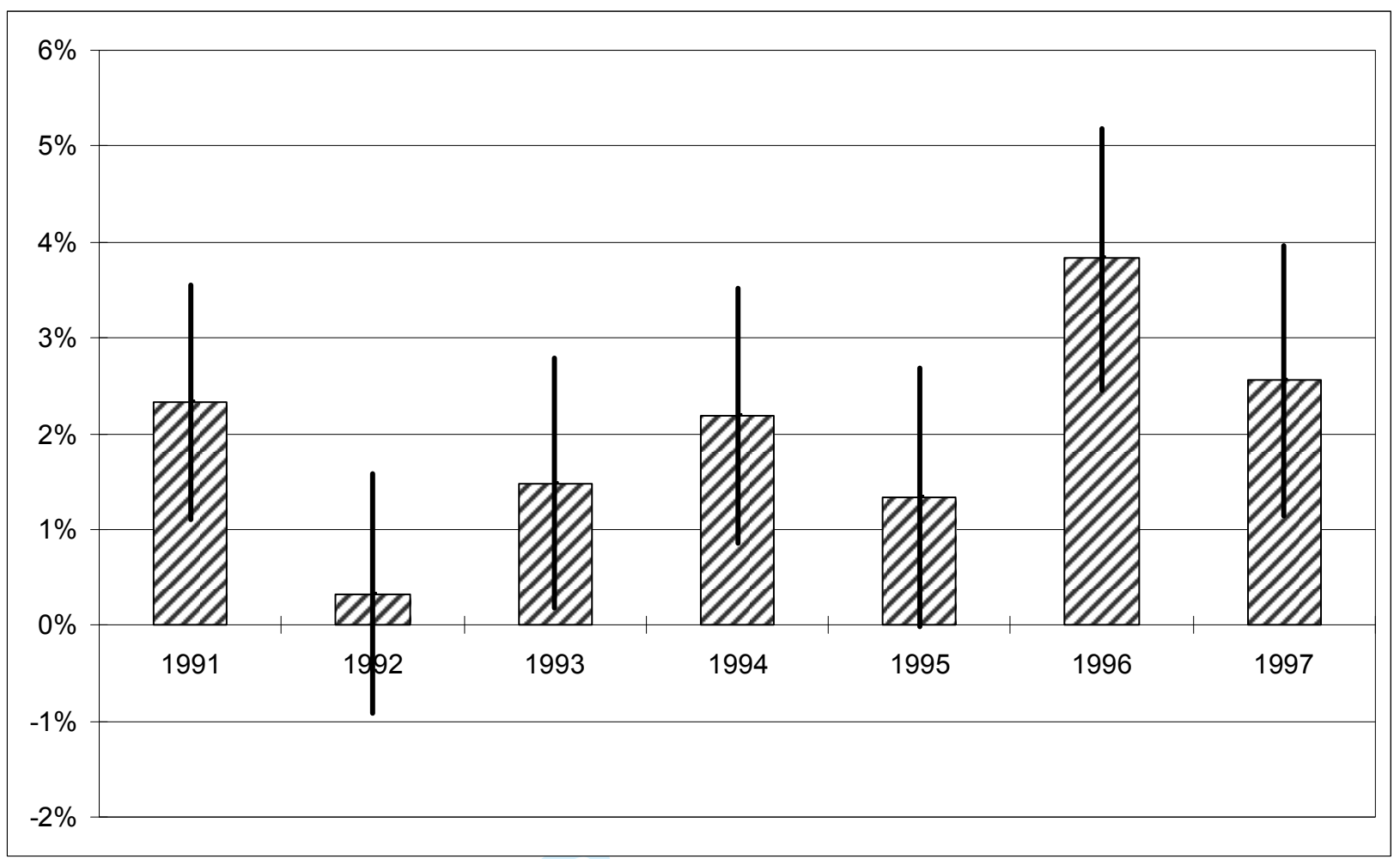

Figure 1:

Raw Wage Differentials of Movers over Stayers and 95 Percent Confidence Interval, 1991 to 1997 


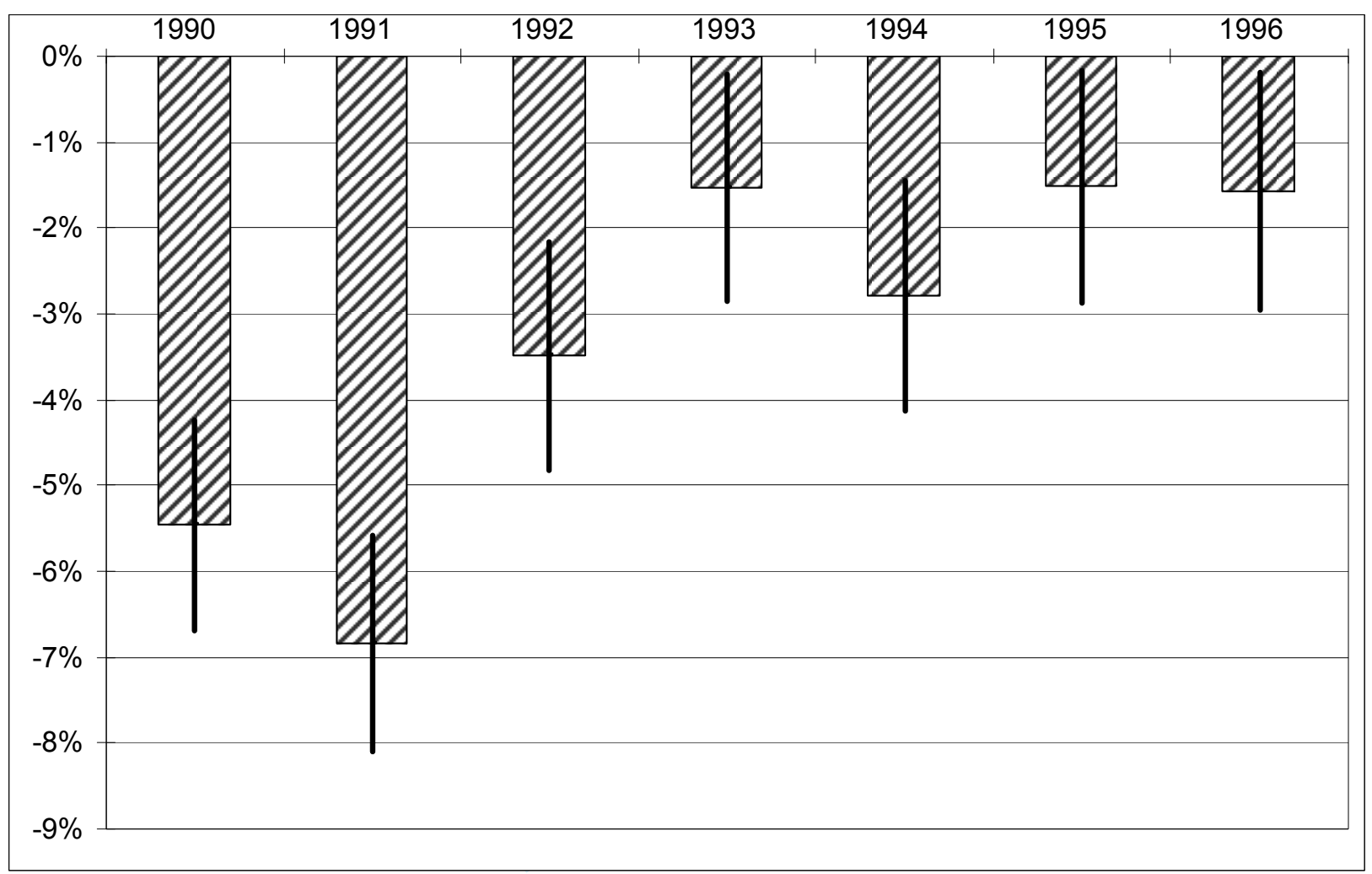

Figure 2:

Raw Wage Disadvantage of Future Movers With Respect to Stayers and 95 Percent Confidence Interval, 1990 to 1996 


\section{References}

ANTEL J. (1991) The wage effects of voluntary labour mobility with and without intervening unemployment, Industrial and Labour Relations Review 44 (2), 299-306.

ANTOLIN P. and BOVER O. (1997) Regional migration in Spain: the effect of personal characteristics and of unemployment, wage and house price differentials using pooled cross-sections, Oxford Bulletin of Economics and Statistics 59 (2), 215-235.

ASHENFELTER O. (1978) Estimating the effect of training programs on earnings, The Review of Economics and Statistics 58, 47-57.

BARTEL A. P. (1980) Earnings growth on the job and between jobs, Economic Inquiry 18, 123-137.

BARTEL A. P. and BORJAS G. J. (1981) Wage growth and job turnover: an empirical analysis, in ROSEN S. (Ed), Studies in Labour Markets, Chicago: University of Chicago Press, 65-90.

BLINDER A. (1973) Wage discrimination: reduced form and structural estimates, Journal of Human Resources 8, 436-455.

BORJAS G. J. (1994) The economics of immigration, Journal of Economic Literature 32, 1667-1717.

BURDETT K. (1978) A theory of employee job search and quit rates, American Economic Review 68, 212-220.

CICCONE A. and HALL R. E. (1996) Productivity and the density of economic activity, American Economic Review 86 (1), 54-70. 
COBB-CLARK D.A. and CROSSLEY T. (2003) Econometrics for evaluations: an introduction to recent developments, The Economic Record 79 (247), 491-511.

DA VANZO J. (1978) Does unemployment affect migration? Review of Economics and Statistics 50, 504-514.

DÈTANG-DESSENDRE C., DRAPIER C. and JAYET H. (2004) The impact of migration on wages: empirical evidence from French youth, Journal of Regional Science 44, 661-691.

ELIASSON K., LINDGREN U. and WESTERLUND O. (2003) Geographical labour mobility: migration or commuting? Regional Studies 37 (8), 827-837.

FARBER H.S. (1999) Mobility and stability: the dynamics of change in labour markets, in ASHENFELTER O. and CARD D. (Eds) Handbook of Labour Economics, Elsevier, Amsterdam, 2439-2483.

GLAESER E.L. and MARÈ D.C. (2001) Cities and skills, Journal of Labour Economics 19, 316-342.

GREENE W.H. and SEAKS T.G. (1991) The restricted least squares estimator: a pedagogical note, Review of Economics and Statistics 73 (3), 563-567.

GREENWOOD M. (1975) Research on internal migration in the United States: a survey, Journal of Economic Literature 8, 397-433.

GREENWOOD M. (1985) Human migration: theory, models and empirical studies, Journal of Regional Science 25, 521-544.

HAISKEN-DE NEW J.P. (1996) Migration and the inter-industry wage structure in Germany, Springer Verlag, Heidelberg/ New York. 
HARRIS T.F. and IOANNIDES Y.M. (2000) Productivity and metropolitan density, Discussion Papers Series 0016, Department of Economics, Tufts University.

HARRIS J. and TODARO M. (1970) Migration, unemployment and development: a twosector analysis, American Economic Review 60, 126-142.

HECKMAN J.J., ICHIMURA H., SMITH, J.A and TODD, P. (1998) Characterizing selection bias using experimental data, Econometrica 65 (5), 1017-1098.

HECKMAN J.J., LALONDE R.J. and SMITH J.A. (1999) The economics and econometrics of active labour market programs, in Ashenfelter O. and Card D., (eds), Handbook of Labour Economics 3a, Amsterdam, 1865-2097.

HEITMUELLER A. (2004) Job mobility in Britain: are the Scots different? Evidence from the BHPS, Scottish Journal of Political Economy 51 (3), 329-358.

HENDERSON J.V. (1986) Efficiency of resource usage and city size, Journal of Urban Economics 19, 47-70.

HERZOG H. and SCHLOTTMANN A. (1981) Economic status and the decision to migrate, Review of Economics and Statistics 63: 590-598.

HUNT J. (2004) Are migrants more skilled than non-migrants? Repeat, return and sameemployer migrants, Canadian Journal of Economics 37 (4), 830-849.

JOHNSON W.R. (1978) A theory of job shopping, Quarterly Journal of Economics 92, 261277.

JOVANOVICH B. (1979) Job matching and the theory of turnover, Journal of Political Economy 87, 972-990. 
KEMPER F.-J. (2004) Internal migration in eastern and western Germany: Convergence or divergence of spatial trends after unification? Regional Studies 38 (6), 659-678.

LEUVEN E. and SIANESI B. (2003) PSMATCH2: Stata module to perform full Mahalanobis and propensity score matching, common support graphing, and covariate imbalance testing. http://ideas.repec.org/c/boc/bocode/s432001.html.

LIGHT A. and MCGARRY K. (1998) Job change patterns and the wages of young men, Review of Economics and Statistics 80 (2), 276-286.

MINCER J. (1974) Schooling, experience and earnings, New York, National Bureau of Economic Research.

MINCER J. (1986) Wage changes in job changes, Research in Labour Economics 8, 171-197.

MINCER J. and JOVANOVICH B. (1981) Labour mobility and wages, in ROSEN S. (Ed), Studies in Labour Markets, Chicago, University of Chicago Press, pp. 21-63.

MOOMAW R.L. (1981) Productivity and city size: a critique of the evidence, Quarterly Journal of Economics 96 (4), 675-688.

MOOMAW R.L. (1985) Firm location and city size: reduced productivity advantages as a factor in the decline of manufacturing in urban areas, Journal of Urban Economics 17 (1), 73-89.

MUNASINGHE L. and SIGMAN K. (2004) A hobo syndrome? Mobility, wages and job turnover, Labour Economics 11, 191-218.

NAKOSTEEN R. A. and WESTERLUND O. (2004) The effects of regional migration on gross income of labour in Sweden, Papers in Regional Science 83, 581-595. 
NIVALAINEN S. (2005) Interregional migration and post-move employment in two-earner families: evidence from Finland, Regional Studies 39 (7), 891-907.

OAXACA R. (1973) Male-female wage differentials in urban labour markets, International Economic Review 14, 693-709.

OI W. and IDSON J.L. (1999) Firm size and wages, in ASHENFELTER O. and CARD D. (Eds) Handbook of Labour Economics, Elsevier, Amsterdam, 2165-2214.

PEKKALA S. (2002) Migration and individual earnings in Finland: a regional perspective, Regional Studies 36 (1), 13-24.

PEKKALA S. and TERVO H. (2002) Unemployment and migration: does moving help? Scandinavian Journal of Economics 104 (4), 621-639.

PERI G. (2001) Young people, skills and cities, CESifo Working Paper No. 610.

PISSARIDES C.A. and WADSWORTH J. (1989) Unemployment and the inter-regional mobility of labour, Economic Journal 99, 739-755.

ROSENBAUM P.R. and RUBIN D.B. (1983) The central role of the propensity score in observational studies for causal effects, Biometrika 70 (1), 41-55.

ROY A.D. (1951) Some thoughts on the distribution of earnings, Oxford Economic Papers 3, $135-146$.

RUBIN D.B. (1974) Estimating causal effects of treatments in randomized and nonrandomized studies, Journal of Educational Psychology 63, 688-701.

SEGAL D. (1976) Are there returns to scale in city size? Review of Economics and Statistics 58, 339-350. 
SJAASTAD L. (1962) The costs and returns of human migration, Journal of Political Economy 70, 80-93.

SMITH J.A. and TODD P.E. (2005) Does matching overcome LaLonde's critique of nonexperimental estimators? Journal of Econometrics 125, 305-353.

SVEIKAUSKAS, L.A. (1975) The productivity of cities, Quarterly Journal of Economics 89, 393-413.

TERVO H. (2000) Post-migratory employment prospects: evidence from Finland, Labour 14, 331-350.

TOPEL R.H. and WARD M.P. (1992) Job mobility and the careers of young men, Quarterly Journal of Economics 107, 439-479.

YANKOW J.J. (2003) Migration, job change, and wage growth: a new perspective on the pecuniary return to geographic mobility, Journal of Regional Science 43, 483-516. 


\section{Endnotes}

${ }^{1}$ The standard human capital model of migration predicts that workers migrate when the discounted value of real income available at a potential destination exceeds that at the origin by more than the costs of moving (SJAASTAD, 1962).

${ }^{2}$ TOPEL and WARD (1992) state that job search plays a crucial role for wage growth; they estimate that about $1 / 3$ of overall wage growth in the first decade of working life can be attributed to job switching.

${ }^{3}$ Some older studies dealing with the determinants affecting the probability of migration are DA VANZO (1978) and HERZOG and SCHLOTTMANN (1981) for the US. For a survey of other relevant studies see GREENWOOD $(1975,1985)$.

${ }^{4}$ Spatial differences in productivity are crucial for explaining spatial wage differentials. Empirical studies in this context typically find a statistically significant positive relationship between density measures of economic activity and productivity (e.g. CICCONE and HALL, 1996; HARRIS and IOANNIDES, 2000). This supports the results of previous studies focussing on the positive effects of city population or industry employment on productivity (e.g. SVEIKAUSKAS, 1975; SEGAL, 1976; MOOMAW, 1981, 1985; HENDERSON, 1986). ${ }^{5}$ In our data source gross daily earnings are calculated as average over the observed employment period for each person. The notions wages and earnings are used synonymously throughout this paper.

${ }^{6}$ For an overview of region types according to this classification see table A1 in the Appendix.

${ }^{7}$ See, for instance, KEMPER (2006) for an exploration of migration patterns in Western and Eastern Germany.

${ }^{8}$ This definition does not differentiate between migration and commuting. In analogy to the distinction made by ELIASSON et al. (2003, p.831), the definition of movers in our paper includes the following categories: (i) workers who change their region type of residence and the region type of work place; (ii) workers who do not change their place of residence, but start commuting to a different type of region; (iii) commuters who do not change their place of residence, but change the region type where the work place is located. Because our definition of mobility is based on region type, our concept of mobility is predominantly related to the first category. Note that adjacent regions are in many cases of the same type.

${ }^{9}$ The described differences are robust within the sample period 1990 to 1997.

${ }^{10}$ The measure of concentration is calculated as: $100 *$ share of movers of this category in total movers divided by the share of movers and stayers of this category in total workers.

${ }^{11}$ HUNT (2004) states that those results are strongly influenced by a special group of movers. Workers who migrate from one state to another without changing the employer are more highly educated than stayers.

${ }^{12}$ Here and in the following potential experience in years is measured as age minus average duration of education minus 6 . For low-skilled workers without an upper secondary education we assume 10 years as the average educational period, for low-skilled workers with an upper secondary education 13 years, for skilled workers 12.5 and 15 years respectively, for highlyskilled workers holding a polytechnic type of degree 16 years and for highly-skilled alumni of a university 18 years.

${ }^{13}$ The potential work experience is categorized as follows: low experience: 0 - 9 years; medium experience: 10 -19 years; high experience: 20 or more years. In order to avoid problems with cell sizes being too small, we aggregated the BBR-region types and firm size categories (see tables A1 and A2 in the Appendix).

${ }^{14}$ For some years in the sample the share of movers is even under-represented in this region type. In 1994 and 1992, for example, the share of mobile workers in RT1 was just 49\%, while more than $50 \%$ of all stayers worked in this region type. 
${ }^{15}$ See MINCER (1974).

${ }^{16}$ Here we included a category "firm size missing".

${ }^{17}$ All workers except for low-skilled male and female workers are considered to be qualified. All interactions are defined for the linear and quadratic experience variable.

${ }^{18} \mathrm{We}$ calculated corresponding estimates for all successive pairs of years in our sample. It turns out that the findings are sufficiently robust over time. In order to save space, we present the results in the following for the most recent years only. The results for other pairs of years are available from the authors on request.

${ }^{19}$ The differential of low-skilled male workers relative to the average in the economy, for example, is obtained as $\hat{a}_{1,1}=-\AA_{\mathrm{a}}^{6}{ }_{n=2}^{6} w_{n} \hat{a}_{1, n}$, where $w_{n}$ denotes the share of category $n$ workers in total employment. The skill differentials of workers in categories $n=(2,3, \ldots, 6)$ are recalculated according to the formula $\stackrel{a}{a, n}_{1, n}=\hat{a}_{1,1}+\hat{a}_{1, n}$. A corresponding procedure was applied to the coefficients of firm size and region type category variables as well.

${ }^{20}$ An explanation of the BLINDER- OAXACA (1973) type decomposition technique is given in the Appendix.

${ }^{21}$ The differentiation by gender and firm size is neglected to keep the table readable.

${ }^{22}$ This is in accordance with the findings of YANKOW (2003) for the US. He points to the fact that this group of migrants searches for immediate wage gains, while highly educated young migrants invest in their human capital.

${ }^{23}$ Note that the overall differential between highly-skilled movers and stayers in RT1 is negative, while the differential is positive for all experience groups. This is due to the fact that experience (or age) of movers and stayers differs markedly. Typically the group of young or not experienced workers is clearly over-represented in the group of movers. The fact that this group earns significantly less than the high-experience group explains the negative difference $(-2.53)$ for the category RT1/ highly-skilled.

${ }^{24}$ A further objection against our method is that only workers are considered who are employed before and after moving. If participation and employment rates vary systematically over types of regions, our results cannot be generalized to the whole working age population. PEKKALA and TERVO (2002) present an approach which explicitly takes account of this selectivity issue. Their approach requires instruments which are not available in our data set. However, we checked the existence of a possible influence of the type of region on employment and participation rates. A scatter plot between population density and employment or participation rates across 439 German NUTS 3 regions shows no significant relationship. Therefore, we feel confident that this possible source of bias in our results is not substantial. ${ }^{25}$ For an overview of recent developments of this approach see COBB-CLARK and CROSSLEY (2003) or SMITH and TODD (2005).

${ }^{26}$ See ROY (1951) and RUBIN (1974).

${ }^{27}$ The basic idea goes back to the seminal contribution of ROSENBAUM and RUBIN (1983).

${ }^{28}$ The results of the probit model are not documented in the paper, but are available on request from the authors. For the calculation of the matching model we used the Psmatch2 Stata module (Version 3.0.0) by LEUVEN and SIANESI (2003).

${ }^{29}$ We conducted the usual diagnostics on the success of matching without finding any clues for questioning the results. The common support assumption is fulfilled in our case. After matching, the differences in characteristics between movers and controls are statistically insignificant.

${ }^{30}$ The results are available from the authors on request. 